\title{
Az additív gyártás hatásai az ausztenites acél mechanikai és korróziós tulajdonságaira
}

\section{Effects of Additive Manufacturing on the Mechanical and Corrosion Properties of Austenic Stainless Steel}

\author{
Maróti János Endre, ${ }^{1}$ Kemény Dávid Miklós, ${ }^{2}$ Károly Dóra ${ }^{3}$ \\ Budapesti Müszaki és Gazdaságtudományi Egyetem, Gépészmérnöki Kar, Anyagtudomány és Technológia \\ Tanszék, Budapest, Magyarország \\ ${ }^{1}$ maroti@eik.bme.hu \\ ${ }^{2}$ kemenydavid@edu.bme.hu \\ ${ }^{3}$ kdora@eik.bme.hu
}

\begin{abstract}
Additive manufacturing (AM) offers the possibility to produce complex parts without the design constraints of traditional manufacturing routes. Our aim was to determine different mechanical and corrosion properties of direct metal laser sintered austenitic stainless steel (X2CrNiMo17-12-2) material with tensile test, Charpy impact test, scanning electron microscopy and corrosion test. The measured values were evaluated, and our results compared with literary values, furthermore, we also examined how the printing direction affects the properties.
\end{abstract}

Keywords: additive manufacturing, austenitic stainless steel, corrosion, mechanical testing.

\section{Összefoglalás}

Az additív gyártástechnológia lehetőséget nyújt komplex alkatrészek gyártására a hagyományos gyártási útvonalak tervezési korlátai nélkül. Kutatásunk célja közvetlen lézeres fémszinterezéssel előállított ausztenites korrózióálló acél (X2CrNiMo17-12-2) anyag különböző mechanikai és korróziós tulajdonságainak meghatározása volt szakító, Charpy-féle ütő, pásztázó elektronmikroszkópos és korróziós vizsgálatokkal. A mért értékek kiértékelését követően a kapott eredményeket összehasonlítottuk a szakirodalomban megtalálhatókkal, valamint azt is vizsgáltuk, hogy a rétegépítési irány milyen mértékben befolyásolja az anyag mechanikai tulajdonságait.

Kulcsszavak: additív gyártás, ausztenites korrózióálló acél, korrózió, mechanikai vizsgálat.

\section{Bevezetés}

Az additív gyártással készült termékek egyre szélesebb körben terjednek el, a termékek minősége fokozatosan javul, és egyre jobban megfelelnek az iparban használatos minőségi elvárásoknak. Emellett olyan geometriák előállítását is lehetővé teszi az additív gyártás, amely más alakítási eljárással nem lehetséges vagy nagyon költséges [1].

A termékgyártás során több fázist különítünk el. Szükség van egy 3D-s modellre, amelyet egy adott
CAD- (Computer Aided Design) szoftverrel lehet megtervezni. Az így kapott modellt STL- (Standard Tessellation Language) formátumra konvertáljuk, amely megteremti a kapcsolatot a 3D-s szoftver és az additív gyártást végző berendezés között. Az STL-fájlformátum a modell felületét háromszögekkel követi le, így a háromszögek méretcsökkentésével a modell pontossága növelhető $[1,2]$.

Az additív gyártási eljárásoknak hét nagyobb ágát [3] különböztethetjük meg az alapján, hogy 
milyen felépítési elv szerint építik meg a háromdimenziós testet. Az általunk használt próbatestek az úgynevezett közvetlen lézeres fémszinterezés (DMLS, Direct Metal Laser Sintering) elnevezésű porágyolvasztási eljárással készültek, amelynek az energiaforrása a lézersugár. Ennél alapanyagként fémötvözet-porokat használnak. Elsőként az építési platformra a kívánt anyagból készült port adagolnak 50-100 $\mu$ m vastagságban. Ezt követően a kialakítandó keresztmetszetet lézersugárral megvilágítják, és ezzel kis térfogaton megolvasztják az anyagot. A réteg létrehozása után az építési platform lejjebb mozdul, és a gép egy újabb por réteget adagol [1, 2]. A DMLS legfontosabb előnye, hogy nagy geometriai pontosság és jó felületi minőség érhető el támaszanyag és utókezelés nélkül. Az előmelegítés miatt a termékekben kisebb lesz a maradó feszültség is. Ezt az eljárást jól lehet alkalmazni nagy szilárdságú anyagoknál is [4, 5].

Az eddigi kutatások azt mutatták, hogy a gyártástechnológiai változók, azaz a lézernyaláb pásztázási sebessége, a lézernyaláb pásztázási vonalai közötti távolság, a lineáris, felületi és térfogati energiasűrűség változtatása és egymáshoz vett viszonya [6], továbbá a munkadarab porozitása [7] befolyásolja legjobban a munkadarabok mikroszerkezeti és mechanikai tulajdonságait.

Érdekes kérdés a különbözően bonyolult geometriájú orvostechnikai implantátumok (pl. koszorúérsztentek) additív gyártással való gyárthatóságának vizsgálata. Így kutatásunk célja ennek megfelelően egy gyakran alkalmazott biokompatibilis anyag, az ausztenites korrózióálló acél vizsgálatáról szól.

\section{Anyagok, eszközök, módszerek}

Minden méréshez X2CrNiMo17-12-2 acél alapanyagú, additívan EOS M100 DMLS 3D nyomtatóval (jele: A) és hagyományosan (jele: H) gyártott próbatesteket használtunk.

\subsection{Charpy-féle ütővizsgálat}

A Charpy-féle ütővizsgálatnál 6 darab $l_{1}=55 \mathrm{~mm}$ és $l_{2}=10 \mathrm{~mm}$ élhosszúságú, $h=2,5 \mathrm{~mm}$ vastagságú, valamint a próbatest hosszabbik oldalának közepén $2 \mathrm{~mm}$ mélységü, $45^{\circ}$-os $\mathrm{V}$ bemetszésü próbatesteket használtunk. Ezeknek fele additívan gyártott, a többi hagyományos tömbi anyagból lett kimunkálva. Továbbá mértünk három szabványosan kialakított próbatesttel, amelyek mérete $55 \times 10 \times 10 \mathrm{~mm}, 2 \mathrm{~mm}$ mélységű $45^{\circ}$-os V bemetszéssel. A Charpy-féle ütővizsgálatot WPN márkájú Charpy-féle ütőberendezésen végeztük, szobahőmérsékleten [8] szerint.

\subsection{Szakítóvizsgálat}

A szakítóvizsgálathoz összesen 16 darab additívan gyártott, A jelü, lapos próbatestet használtunk. Ezek közül 10 darab teljes hosszúsága $L_{t}=70 \mathrm{~mm}$, eredeti jeltávolsága $L_{0}=27,5 \mathrm{~mm}$, vastagsága $a_{0}=2 \mathrm{~mm}$, szélessége $b_{0}=2,5 \mathrm{~mm}$, vizsgálati hoszsza pedig $L_{c}=40 \mathrm{~mm}$ volt (a továbbiakban hosszú próbatest), a többi jeltáv nélküli, amelyeknek teljes hosszúsága $L_{t}=37 \mathrm{~mm}$, vastagsága $a_{0}=2 \mathrm{~mm}$, szélessége $b_{0}=6 \mathrm{~mm}$ volt (a továbbiakban rövid próbatest).

Továbbá a próbatestek rétegépítési irányát is változtattuk, vertikális (a támaszanyag a munkadarab kisebb oldallapján volt elhelyezve) és horizontális (a támaszanyag a munkadarab nagyobb oldallapján volt elhelyezve) irányban. A hosszú próbatestek fele horizontálisan, fele vertikálisan lett gyártva, a rövidek közül egy horizontálisan, a többi vertikálisan. Eredményeinket a gyártói adatokkal hasonlítottuk össze, amely szerint a horizontális próbatesteknél: $R_{m}=650 \mathrm{MPa}$, $R_{p 0,2}=535 \mathrm{MPa}, \mathrm{A}=35 \%$, vertikális próbatesteknél pedig $R_{m}=590 \mathrm{MPa}, R_{p 0,2}=490 \mathrm{MPa}, A=45 \%$ [9].

A vizsgálatot MTS 810 hidraulikus univerzális anyagvizsgálógépen, $3 \mathrm{~mm} / \mathrm{min}$ keresztfejsebességgel végeztük és értékeltük ki az MSZ EN ISO 6892-1 szabványnak [10] megfelelően.

\subsection{Korróziós vizsgálat}

A korróziós vizsgálatokhoz $d=15 \mathrm{~mm}$ átmérőjü és $h=6 \mathrm{~mm}$ magasságú, henger alakú próbatesteket használtunk. Korróziós cellánk részei (1. ábra): túltelített KCl-oldatos kalomel (referencia) elektróda, amelyhez képest mérjük a feszült-

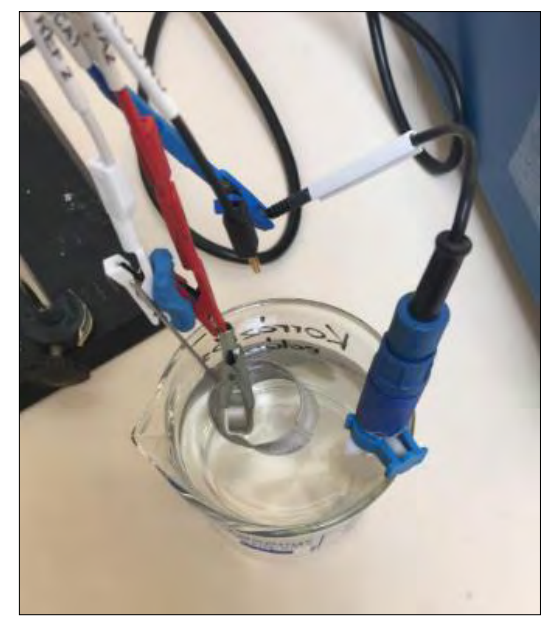

1. ábra. Korróziós mérési elrendezés 
ség változását, Pt-elektróda, amely ellen-elektródaként funkcionál, potenciosztát és számítógép, 250 ml-es üvegedény, digitális fütőlap és állvány.

A vizsgálatokhoz $0,9 \%$-os és 3,5\%-os NaCl-oldatot használtunk korróziós közegnek, amellyel a szervezetben uralkodó és tengervizes környezetet szimulálunk. A fiziológiás sóoldatos mérés során az oldatot $37 \pm 2{ }^{\circ} \mathrm{C}$-ra fütöttük, ezzel is a szervezetben uralkodó viszonyokat közelítve.

A 0. időpillanatban felvettük az áramsűrűség-feszültség diagramot, más néven Tafel-görbét, majd ezt megismételtük 1, 2, 3, 4 és 5 óra elteltével. A vizsgálatokat az ASTM G 102 szabvány [11] szerint végeztük és értékeltük ki.

Hasonló méréseket végzett $L$. Absora és munkatársai, akik 3\%-os NaCl-oldatban mérték az általunk vizsgált X2CrNiMo17-12-2 acél korrózióját, a korróziósebességre nekik 0,0071 mm/év adódott [12].

A vizsgált anyagok anyagösszetételét Zeiss EVO M10 pásztázó elektronmikroszkóppal (SEM) és a hozzá tartozó Octane elect típusú EDAX (energia diszperzív spektrométer) kiegészítővel határoztuk meg. A korróziós mérés előtt és után felvételeket készítettünk a próbatestek felületéről $20 \mathrm{kV}$ gyorsítófeszültséggel szekunder elektron detektorral.

\section{Eredmények}

\subsection{Charpy-féle ütővizsgálat}

A Charpy-féle ütővizsgálatnál meghatároztuk a kiszélesedést ( $\left.e=x-x_{0}, \mathrm{~mm}\right)$, az ütőmunkát (KV, $\mathrm{J})$ és a fajlagos ütőmunkát $\left(\mathrm{KCV}, \mathrm{J} / \mathrm{mm}^{2}\right.$ ). A próbatestekből kapott eredményeinket az 1. táblázat foglalja össze.

A kiszélesedést, ütőmunkát és a fajlagos ütőmunkát a H10-jelü szabványos próbatestekre is megmértük (2. táblázat).

A töretfelületekről pásztázó elektronmikrosz-

1. táblázat. Az A-jelü és a H-jelü, vékony próbatestek ütővizsgálati eredményei

\begin{tabular}{|c|c|c|c|c|}
\hline \multicolumn{2}{|c|}{ Próbatest } & \multirow{2}{*}{$\begin{array}{c}\mathbf{e} \\
(\mathbf{m m})\end{array}$} & \multirow{2}{*}{$\begin{array}{c}\text { KV } \\
(\mathrm{J})\end{array}$} & \multirow{2}{*}{$\begin{array}{c}\mathrm{KCV} \\
\left(\mathrm{J} / \mathbf{m m}^{2}\right)\end{array}$} \\
\hline típus & szám & & & \\
\hline $\mathrm{A} 2,5$ & 1 & 0,641 & 18 & 0,96 \\
\hline $\mathrm{A} 2,5$ & 2 & 0,917 & 18 & 0,96 \\
\hline $\mathrm{A} 2,5$ & 3 & 0,625 & 18 & 0,96 \\
\hline $\mathrm{H} 2,5$ & 1 & 1,07 & 27 & 1,44 \\
\hline $\mathrm{H} 2,5$ & 2 & 1,07 & 28 & 1,49 \\
\hline $\mathrm{H} 2,5$ & 3 & 1,09 & 29 & 1,55 \\
\hline
\end{tabular}

2. táblázat. H-jelű szabványos próbatestek fajlagos ütömunkája és kiszélesedése

\begin{tabular}{|c|c|c|c|c|}
\hline \multicolumn{2}{|c|}{ Próbatest } & \multirow{2}{*}{$\begin{array}{c}\mathrm{e} \\
(\mathrm{mm})\end{array}$} & \multirow{2}{*}{$\begin{array}{l}\text { KV } \\
\text { (J) }\end{array}$} & \multirow{2}{*}{$\begin{array}{c}\mathrm{KCV} \\
\left(\mathrm{J} / \mathbf{m m}^{2}\right)\end{array}$} \\
\hline típus & szám & & & \\
\hline $\mathrm{H} 10$ & 1 & 1,4 & 99 & 1,32 \\
\hline $\mathrm{H} 10$ & 2 & 1,2 & 118 & 1,57 \\
\hline $\mathrm{H} 10$ & 3 & 1,1 & 134 & 1,65 \\
\hline
\end{tabular}
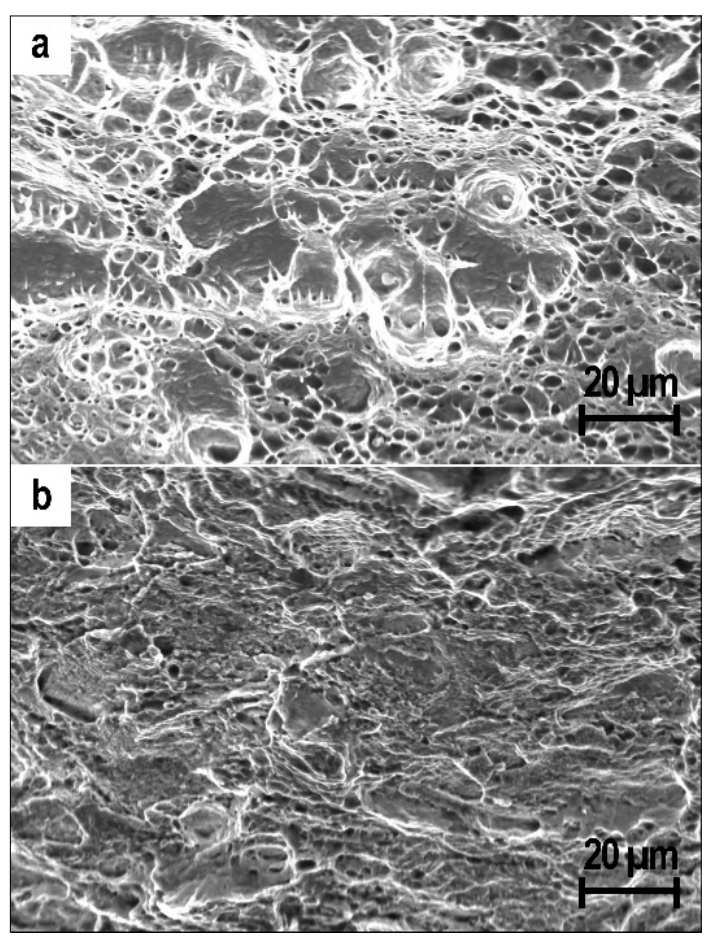

2. ábra. Pásztázó elektronmikroszkópos kép a töretfelületről ütővizsgálat után, additívan gyártott próbatest (a), hagyományosan gyártott próbatest (b)

kóppal felvételeket készítettünk (2. ábra). A felületek szakadozott, tompa fényü jellege nem tér el nagyban az additívan gyártott és a hagyományos próbatestek esetén, de az additívan gyártott mintáknál megfigyelhető a porozitásból fakadó gödrök jelenléte.

\subsection{Szakítóvizsgálat}

A hosszú próbatestek közül egy vertikálisan épített és egy horizontálisan épített próbatest szakítódiagramját ( $F-\Delta L$, erő-elmozdulás diagram) ábrázoltuk a 3. ábrán. Azért nem ábrázoltuk az összes próbatest szakítódiagramját, mivel így sokkal szemléletesebben látszik a két rétegépítési irány közötti különbség. 
A hosszú próbatestek átlagos egyezményes folyáshatárát $\left(R_{p 0,2}\right)$, rugalmassági modulusát $(E)$, szakítószilárdságát $\left(R_{m}\right)$, százalékos szakadási nyúlását (A) és kontrakcióját (Z) a 3. táblázatban tüntettük fel a szórással együtt.

A mérést a rövid próbatestekre is megismételtük. Ezen próbatestek közül, a jobb szemléltethetőség miatt, ismét egy vertikálisan és horizontálisan gyártott munkadarab szakítógörbéit ábrázoltuk a következő ábrán (4. ábra).

A rövid próbatestek egyezményes folyáshatárának, szakítószilárdságának és kontrakciójának átlagát és szórását a 4. táblázatban foglaltuk össze.

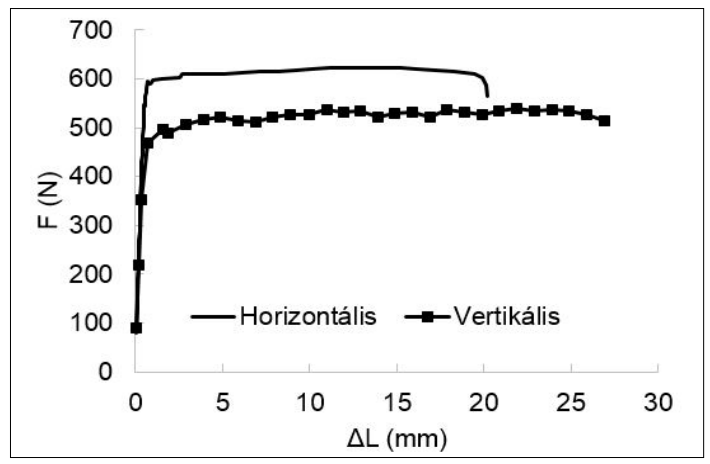

3. ábra. Hosszú próbatestek szakítódiagramja

3. táblázat. A hosszú próbatestek jellemzői

\begin{tabular}{|c|c|c|c|c|c|}
\hline $\begin{array}{c}\text { Réteg } \\
\text { ép. ir. }\end{array}$ & $\begin{array}{c}\mathbf{R}_{\text {p02 }} \\
(\mathbf{M p a})\end{array}$ & $\begin{array}{c}\mathbf{E} \\
\mathbf{( G P a )}\end{array}$ & $\begin{array}{c}\mathbf{R}_{\mathbf{m}} \\
\mathbf{( M p a )}\end{array}$ & $\begin{array}{c}\mathbf{A} \\
\mathbf{( \% )}\end{array}$ & $\begin{array}{c}\mathbf{Z} \\
\mathbf{( \% )}\end{array}$ \\
\hline Hor. & $520 \pm 43$ & $138 \pm 16$ & $604 \pm 20$ & $23,83 \pm 2,25$ & $41,8 \pm 7,54$ \\
\hline Vert. & $460 \pm 17$ & $111 \pm 12$ & $558 \pm 18$ & $26,5 \pm 1,9$ & $54 \pm 5,2$ \\
\hline
\end{tabular}

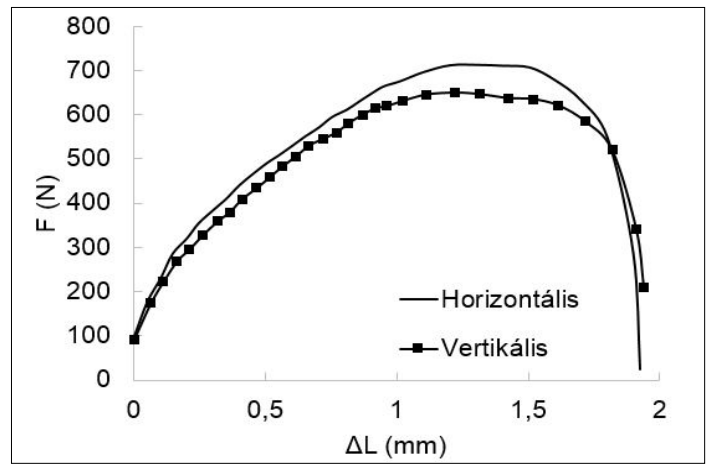

4. ábra. Rövid próbatestek szakítódiagramja

4. táblázat. Rövid próbatestek jellemzői

\begin{tabular}{|c|c|c|c|}
\hline $\begin{array}{c}\text { Réteg } \\
\text { ép. ir. }\end{array}$ & $\begin{array}{c}\mathbf{R}_{\mathbf{p 0 2}} \\
\text { (Mpa) }\end{array}$ & $\begin{array}{c}\mathbf{R}_{\mathbf{m}} \\
(\mathbf{M p a})\end{array}$ & $\begin{array}{c}\mathbf{Z} \\
\mathbf{( \% )}\end{array}$ \\
\hline Hor. & 565 & 735 & 26,2 \\
\hline Vert. & $600 \pm 20$ & $656 \pm 19$ & $39,9 \pm 2,3$ \\
\hline
\end{tabular}

\subsection{Korróziós vizsgálat}

Az 5. ábrán lászik, hogy a szervezetben uralkodó körülményeket szimuláló, közel testhőmérsékleten elvégzett fiziológiás sóoldatos korróziós vizsgálat közben az additívan gyártott minta felületén található gömbök (amelyeket a lézeres olvasztásból fakadó fémfröccsenések okoznak) több helyen leválnak.

A mérések során kapott Tafel-görbék (korróziós áramsűrűség - korróziós potenciál diagram) közül a fiziológiás sóoldatban mérteket közöljük a 6. ábrán. A görbékből megkapjuk a munkadarabra jellemző korróziósebességet. A kiértékelés

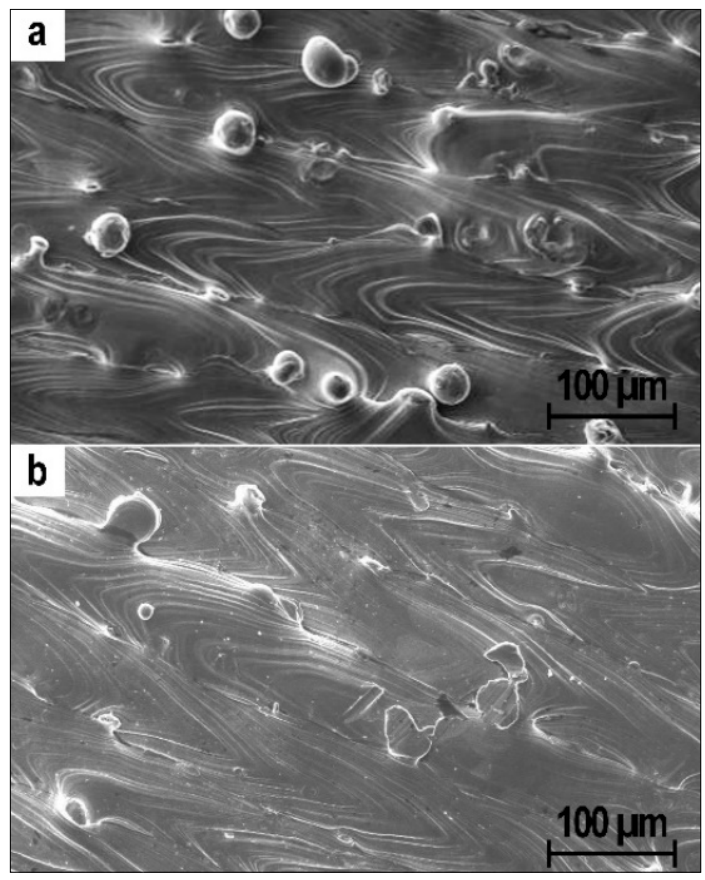

5. ábra. Additívan gyártott próbatest felülete korróziós vizsgálat elött (a) és után (b)

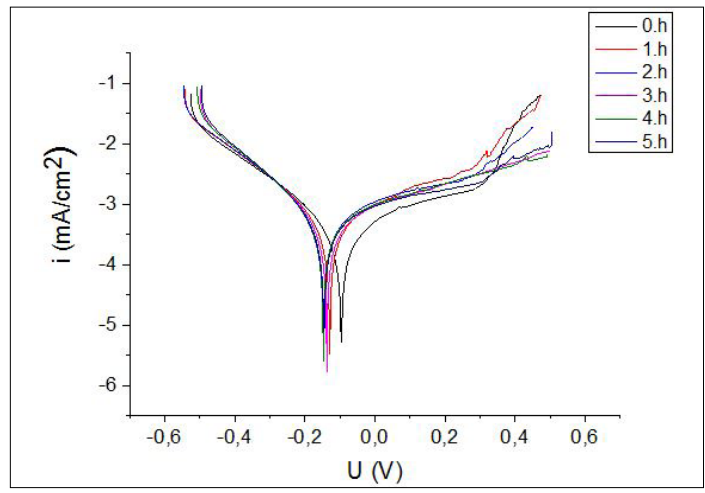

6. ábra. Additívan gyártott próbatest Tafel-görbéi a 0-5. órában 0,9\%-os sóoldatban 
során a Tafel-görbe lineáris szakaszára illesztjük az érintőket, figyelembe véve az egyensúlyi korróziós potenciált $\left(E_{k o r r}\right)$. Az érintők metszéspontja megadja az áramerősséget, amelyet a szükséges képletekbe beírva [11], megkapjuk a korróziósebességet.

A sztereomikroszkóppal készült felvételekről meghatároztuk a próbatestek azon felületét, amelyek érintkeztek a korróziós közeggel. A fiziológiás sóoldatban használt próbatest esetében ez $A=0,88 \mathrm{~cm}^{2}$, míg a tengervizes sóoldat esetében a próbatest $A=0,875 \mathrm{~cm}^{2}$ felületen érintkezett a korróziós közeggel. A tömegszázalékot és atomszázalékot pásztázó elektronmikroszkóp segítségével mértük meg. A próbatestek anyagösszetételét a következő táblázatban (6. táblázat) foglaltuk össze.

Ezek alapján a sürűség $\rho=7,814 \mathrm{~g} / \mathrm{cm}^{3}$, az egyensúlyi tömeg $E_{w}=17,164$. A két oldatban mért korróziósebességeket $\left(\mathrm{v}_{\mathrm{korr}}\right)$ táblázatba foglaltuk (7. táblázat).

A korróziósebességek időbeni változását a 7. ábra mutatja. Láható, hogy a vért szimuláló sóoldatban mért korróziósebesség-értékek az 1., 2. és 3. órában kisebbek, mint tengervizes közegben, majd a 0,9\%-os sóoldatban mért korróziósebességek kiugranak, ami a nagy porozitásnak és a korrózió által okozott felületi hibáknak tudható be. Az általánosságban biokompatibilis anyagok-

6. táblázat. Az additívan gyártott próbatest anyag összetétele

\begin{tabular}{|c|c|}
\hline Elem & Tömegszázalék \\
\hline $\mathrm{Fe}$ & $62,33-63,91$ \\
\hline $\mathrm{Cr}$ & $20,38-22,15$ \\
\hline $\mathrm{Ni}$ & $10,49-12,81$ \\
\hline $\mathrm{Mo}$ & $1,66-2,74$ \\
\hline $\mathrm{Mn}$ & $1,09-2,37$ \\
\hline $\mathrm{Si}$ & $0,13-0,55$ \\
\hline
\end{tabular}

7. táblázat. A-jelü próbatestek korróziósebessége

\begin{tabular}{|c|c|c|}
\hline \multirow{2}{*}{$\mathbf{t}(\mathbf{h})$} & \multicolumn{2}{|c|}{$\mathbf{v}_{\text {korr }}(\mathbf{m m} / \mathbf{e ́ v})$} \\
\cline { 2 - 3 } & $\mathbf{0 , 9 \% ~ N a C l}$ & $\mathbf{3 , 5 \% ~ N a C l}$ \\
\hline 0 & 0,00023 & 0,0035 \\
\hline 1 & 0,00096 & 0,0056 \\
\hline 2 & 0,00133 & 0,0061 \\
\hline 3 & 0,00100 & 0,0050 \\
\hline 4 & 0,01668 & 0,0059 \\
\hline 5 & 0,01541 & 0,0057 \\
\hline
\end{tabular}

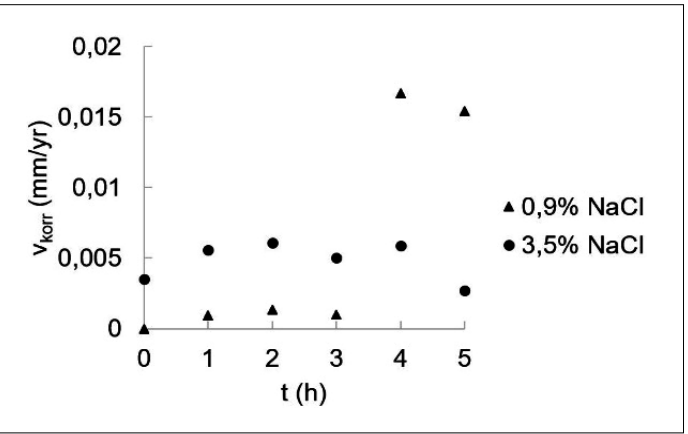

7. ábra. AM-próbatestek korróziósebessége az idő függvényében

ra megengedett maximum $0,13 \mathrm{~mm} / \mathrm{e} v$ értékhez képest viszont minden értékünk kisebb, így az additívan gyártott anyag orvostechnikai felhasználásra korróziós szempontból megfelelő.

\section{Következtetések}

\subsection{Charpy-féle ütővizsgálat}

A két különböző gyártási eljárással gyártott, különböző méretű próbatestek egymással való öszszehasonlításához a fajlagos ütőmunka ideális az ütővizsgálatnál kapott eredmények közül.

A H2,5-jelű próbatestekre az átlagos KCV = 1,493 $\mathrm{J} / \mathrm{mm}^{2}$ adódott, a H10-jelüekre az átlagos $\mathrm{KCV}=$ $1,513 \mathrm{~J} / \mathrm{mm}^{2}$, míg az A2,5-jelü munkadarabokra $\mathrm{KCV}=0,96 \mathrm{~J} / \mathrm{mm}^{2}$. Láthatjuk, hogy az azonos gyártási eljárással gyártott próbatestek között nincs számottevő különbség, vagyis a méretcsökkentés nincs hatással az anyag ezen tulajdonságaira.

Azonban az A és H jelű próbatestek fajlagos ütőmunkái között átlagosan $0,543 \mathrm{~J} / \mathrm{mm}^{2}$ a differencia, ami az additív gyártástechnológiából adódó porozitásnak tudható be.

Minden esetben szívós viselkedést mutattak a próbatestek szobahőmérsékleten.

\subsection{Szakítóvizsgálat}

A szakítóvizsgálat alapján megállapítható, hogy a rövid próbatestek nem alkalmasak a mechanikai tulajdonságok megfelelő meghatározására, mivel geometriájukból adódóan nem lehetett a vizsgálatot megfelelően elvégezni (az extenzométer felhelyezése nem volt lehetséges), valamint a próbatest közepén levő bemetszés feszültséggyüjtő helynek tekinthető.

A hosszú próbatestek eredményei kiadják azt a tendenciát, hogy a horizontálisan nyomtatott próbatestek mechanikai tulajdonságai jobbak, mint a vertikálisan nyomtatott próbatesteké. 
A hosszú próbatesteknél egyezményes folyáshatár esetén $60 \mathrm{MPa}$, rugalmassági modulusz esetén 27 GPa, szakítószilárdság esetén $46 \mathrm{MPa}$ a különbség mindkét esetben a horizontálisan nyomtatott próbatestek javára.

A mért eredményeket a gyártói adatokkal [9] összehasonlítva láthatjuk, hogy az egyezményes folyáshatár, a szakítószilárdság és a szakadási nyúlás is nagyobb a gyártói adatlapon, mint az általunk mért érték. Ennek oka lehet a nem megfelelő nyomtatási beállítások, amelyek nagyobb porozitást okoznak az anyagban.

\subsection{Korróziós vizsgálat}

A kapott korróziósebességeket az irodalommal hasonlítottuk össze. A fiziológiás $0,9 \%$ sóoldatban mért értékek a biokompatibilitáshoz szükséges határértéket nem haladták meg. Az irodalomban 0,0071 mm/év korróziósebességet mértek [12], amíg nekünk 0,0053 mm/év lett. Ez a 0,0018 mm/év különbség az additív gyártástechnológia sajátosságaiból, a felület érdességéből és a porozitás mértékéből adódik.

\section{Köszönetnyilvánítás}

A projekt a Nemzeti Kutatási, Fejlesztési és Innovációs Hivatal támogatásával az NKFIH Alapból valósul meg, a projekt címe: „Egyénre szabott orvos-biológiai implantátumok és segédeszközök új generációs gyártási folyamatának kidolgozása additív technológiákra”, a pályázat azonosító száma: NVKP_16-1-2016-0022. A kidolgozók köszönik a támogatást.

Az eredmények közzétételéhez anyagi hozzájárulást nyújtott a BME Tudományos Diákköri Bizottságának TDK-pályázata. A szerzők köszönik a hozzájárulást.

\section{Szakirodalmi hivatkozások}

[1] B. Redwood, F. Schöffer, B. Garret: The 3D Printing Handbook: Technologies, design and applications. 1. kiadás. Coers \& Roest, Amsterdam, 2017. 123-137.

https://doi.org/10.1007/978-981-13-8281-9
[2] Z. Keresztes, D. Pammer, D. Károly, J.P. Szabó: EBSD examination of Ti-6Al-4V samples prodiced with additive technology. IOP Conference Series: Materials Science and Engineering 426012025 (2018) https://doi.org/10.1088/1757-899X/426/1/012025

[3] MSZ EN ISO/ASTM 52900:2017 Additív gyártás. Általános alapelvek. Terminológia (ISO/ASTM DIS 52900:2017)

[4] X.-Y. Zhang, G. Fang, J. Zhou: Additively Manufactured Scaffolds for Bone Tissue Engineering and the Prediction of their Mechanical Behavior: A Review. Material, 10/1. (2017) 50. https://doi.org/10.3390/ma10010050

[5] $\mathrm{D} \mathrm{Gu}, \mathrm{Y}$. Shen: Processing conditions and microstructural features of porous $316 L$ stainless steel components by DMLS. Applied Surface Science, 255 (5)/1. (2008) 1880-1887. https://doi.org/10.1016/j.apsusc.2008.06.118

[6] S.Y. Chen, et al.: Microsstructure and mechanical properties of open-cell porous TI-6AL-4V fabricated by selective laser melting. Journal of Alloys and Compounds, 713. (2017) 248-254. https://doi.org/10.1016/j.jallcom.2017.04.190

[7] M. Mahmoudi, et al.: On the printability and transformation behavior of nickel-titanium shape memory alloy fabricated using laser power-bed fusion additive manufacturing. Journal of Manufacturing Processes, 35. (2018) 672-680. https://doi.org/10.1016/j.jmapro.2018.08.037

[8] MSZ EN ISO 148-1:2017 Fémek. Charpy-féle ütővizsgálat. 1. rész: Vizsgálati módszer (ISO 148-1:2016)

[9] EOS Anyag adatlap, 316L. (2019. 02. 20.) www.eos.info/material-m

[10] MSZ EN ISO 6892-1:2016 Fémek. Szakítóvizsgálat. 1. rész: Vizsgálat szobahőmérsékleten (ISO 6892-1:2016)

[11] ASTM G102 - 89(2015): Standard Practice for Calculation of Corrosion Rates and Related Information from Electrochemical Measurements.

[12] L. Absora, et al.: Corrosion of mild steel and $316 L$ austenitic stainless steel with different surface roughness in sodium chloride saline solutions. WIT Transactions on Engineering Sciences, 65. (2009) 168. https://doi.org/10.2495/ECOR090161 